\title{
PENERAPAN MODEL PEMBELAJARAN TAI UNTUK MENGETAHUI KEMAMPUAN PEMECAHAN MASALAH MATEMATIS
}

\author{
${ }^{1}$ Dian Apriani, ${ }^{2}$ Eka Nita Permata \\ ${ }^{1,2}$ FKIP Universitas Tamansiswa Palembang \\ *dian_apriani@unitaspalembang.ac.id
}

\begin{abstract}
The purpose of this study was to determine the students' problem solving skills after applying the TAI learning model. The research method uses a pseudo experimental method of the category one short case study. The subjects of this study were students of class VIII.D, amounting to 41 students. Data collection techniques used in this study were test and observation techniques. The data analysis technique used is quantitative descriptive statistics. The conclusion of this study is mathematics learning using the TAI cooperative learning model can be applied to students of class VIII SMP Negeri 40 Palembang can be seen from the results of student observations with an average of 77.27 good categories and mathematical problem solving abilities of students after applying the type of cooperative learning model TAI is categorized as good based on the final test results with an average value of 84.63 .
\end{abstract}

Key Words: Troubleshooting, TAI

\begin{abstract}
Abstrak: Tujuan penelitian adalah untuk mengetahui kemampuan pemecahan masalah siswa setelah diterapkan model pembelajaran TAI. Metode penelitian menggunakan metode eksperimen semu kategori one short case study. Subjek penelitian ini adalah siswa kelas VIII.D yang berjumlah 41 siswa. Teknik pengumpulan data yang digunakan dalam penelitian ini adalah teknik tes dan observasi. Teknik analisis data yang digunakan adalah statistik deskriptif kuantitatif. Simpulan dalam penelitian ini adalah pembelajaran matematika dengan menggunakan model pembelajaran kooperatif TAI dapat diterapkan pada siswa kelas VIII SMP Negeri 40 Palembang dapat dilihat dari hasil observasi siswa dengan rata-rata 77,27 kategori baik dan kemampuan pemecahan masalah matematis siswa setelah diterapkan model pembelajaran kooperatif tipe TAI dikategorikan baik dilihat dari hasil tes akhir dengan nilai rata-rata 84,63.
\end{abstract}

Kata Kunci: Pemecahan Masalah, TAI

\section{PENDAHULUAN}

Matematika merupakan salah satu ilmu dasar yang dipelajari manusia dari berbagai tingkat pendidikan dan berbagai usia, mulai dari TK hingga ke perguruan tinggi. Matematika merupakan salah satu mata pelajaran yang penting keberadaanya, salah satunya digunakan untuk memecahkan masalah kehidupan sehari-hari. Menurut Maulaty (2014) menyatakan bahwa pada dasarnya sebagian besar para pelajar merasa malas, tidak tertarik bahkan kalau bisa mereka ingin menghindar dari mata pelajaran matematika. Matematika dianggap sebagai pelajaran yang sulit dan rumit karena selalu berhubungan dengan 
angka, rumus dan hitung menghitung. Mereka pun tidak berniat untuk mempelajarinya, kecuali karena tuntutan materi. Meskipun demikian semua orang harus mempelajari matematika. Fathani (2009) menyatakan bahwa matematika itu penting baik sebagai alat bantu, sebagai ilmu, sebagai pembentuk sikap maupun sebagai pembimbing pola pikir.

Kemampuan pemecahan masalah perlu dikuasai oleh siswa guna mendorong mereka menjadi pemecah masalah yang baik yang mampu menghadapi masalah di sekolah maupun dalam kehidupan sehari-hari.

Sejalan dengan hal tersebut menurut Conney dalam Hudoyo yang dikutip oleh Risnawati (2008) menyatakan bahwa mengajarkan penyelesaian masalah kepada peserta didik, memungkinkan peserta didik itu menjadi lebih analitis didalam mengambil keputusan didalam hidupnya. Dengan kata lain, bila peserta didik dilatih menyelesaikan masalah, maka peserta didik itu akan mampu mengambil keputusan, sebab peserta didik itu telah menjadi terampil tentang bagaimana mengumpulkan informasi yang relevan, menganalisis informasi, dan menyadari betapa perlunya meneliti kembali hasil yang telah diperolehnya.

Tetapi pada kenyataannya kemampuan pemecahan masalah siswa masih tergolong rendah. Hal ini dibuktikan dari hasil Laporan Badan Penelitian Dan Pengembangan (Balitbang) tahun 2011 bahwa hasil Survei Trends Internasional Matematics and Science Study (TIMSS) pada tahun 2013 menunjukkan prestasi belajar siswa di Indonesia pada TIMSS tahun 2007 lebih memprihatinkan lagi karena Indonesia berada di peringkat 39 dari 49 negara. Hal serupa pun diperkuat oleh hasil penelitian yang telah dilakukan oleh peneliti di SMP Negeri 40 Palembang yang masih tergolong rendah yaitu dari 9 kelas yang terdiri dari 40 siswa perkelasnya hanya ada $25 \%$ siswa yang memahami soal pemecahan masalah.

Penelitian Mursalin (2013), Sulastri (2013), dan Yani (2015), menyimpulkan bahwa hasil belajar siswa yang diperoleh setelah diterapkan Model Pembelajaran Kooperatif tipe $T A I$, rata-rata dari ketiga peneliti tersebut dikategorikan baik.

\section{TINJAUAN TEORETIS}

\section{Belajar dan Pembelajaran}

Belajar merupakan aktifitas mental atau ( psikhis ) yang terjadi karena adanya interaksi aktif antara individu dengan lingkungannya yang menghasilkan perubahan-perubahan yang bersifat relativ tetap dalam aspekaspek: kognitif, psikomotor dan afektif. Perubahan tersebut dapat berubah sesuatu yang sama sekali baru atau penyempurnaan/penigkatan dari hasil belajar yang telah di peroleh sebelumnya. Siswa adalah penentu terjadinya atau tidak terjadinya proses belajar tersebut.

Dengan demikian belajar dan pembelajaran merupakan hal yang saling berhubungan dan dianggap hal yang menarik untuk dipelajari. Belajar itu sendiri merupakan proses untuk mengetahui dan memahami sesuatu. 
Belajar juga berhubungan dengan siswa. Sedangkan pembelajaran merupakan suatu proses belajar mengajar yang mengandung dua jenis kegiatan yang tidak terpisahkan. Kegiatan tersebut adalah belajar dan mengajar. Kedua aspek ini akan berkolaborasi secara terpadu menjadi suatu kegiatan pada saat terjadi interaksi antara siswa dengan guru, antara siswa dengan siswa, dan antara siswa dengan lingkungan disaat pembelajaran sedang berlangsung.

\section{Model Pembelajaran Kooperatif}

Pembelajaran kooperaif adalah model pembelajaran yang dirancang untuk membelajarkan kecakapan akademik (academic skill), sekaligus keterampilan sosial (social skill) termasuk interpersonal skill (Riyanto, 2009: 26).

Roger dan Johson dalam Suprijono (2009: 58) mengatakan bahwa tidak semua belajar kelompok bisa dianggap pembelajaran kooperatif. Untuk mencapai hasil yang maksimal, lima unsur dalam model pembelajaran kooperatif harus diterapkan. Lima unsur tersebut adalah: 1) Positive Interdependence yaitu saling ketergantungan positif; 2) Personal Responsibility yaitu tanggung jawab perseorangan; 3) Face to face promotive interaction yaitu interaksi promotif; 4) Interpersonal skill yaitu komunikasi antar anggota; dan 5) Group processing yaitu pemprosesan kelompok.

\section{Kemampuan Pemecahan Masalah Matematis}

Pemecahan masalah merupakan bagian dari kurikulum matematika yang sangat penting karena dalam proses pembelajaran maupun penyelesaian, siswa dimungkinkan memperoleh pengalaman menggunakan pengetahuan serta keterampilan yang sudah dimiliki untuk diterapkan pada pemecahan masalah yang bersifat tidak rutin. Melalui kegiatan ini aspek-aspek kemampuan matematika penting seperti penerapan aturan pada masalah tidak rutin, penemuan pola, penggeneralisasian, komunikasi matematika dapat dikembangkan lebih baik. Namun demikian, kenyataan di lapangan menunjukkan bahwa kegiatan pemecahan masalah dalam proses pembelajaran matematika belum dijadikan sebagai kegiatan utama (Suherman dkk, 2003: 89).

\section{Indikator Pemecahan Masalah Matematis Siswa}

Menurut Djamarah (2002), pemecahan masalah merupakan suatu metode yang merupakan suatu metode berpikir, sebab dalam pemecahan masalah dapat digunakan metodemetode lainnya yang dimulai dengan pencarian data sampai dengan penarikan kesimpulan. Karena itu, pembelajaran yang bernuansa pemecahan masalah harus dirancang sedemikian rupa sehingga mampu merangsang siswa untuk berpikir dan mendorong menggunakan pikirannya secara sadar untuk memecahkan masalah. 
Menurut Mawaddah (Hamzah, masalah, yaitu : a) Memahami masalah; 2014) menyebutkan ada empat langkah b) Merencanakan penyelesaian; dan c) dalam pembelajaran pemecahan Menafsirkan hasil yang diperoleh.

Tabel 1.

Pedoman Penskoran Pemecahan Masalah Matematis Siswa

\begin{tabular}{|c|c|c|c|}
\hline No. & $\begin{array}{l}\text { Aspek yang dinilai } \\
\text { (Indikator) }\end{array}$ & Respon Siswa Terhadap Soal & Skor \\
\hline \multirow[t]{4}{*}{1.} & \multirow[t]{4}{*}{ Memahami Masalah } & $\begin{array}{l}\text { Tidak menyebutkan apa yang diketahui } \\
\text { dan ditanyakan }\end{array}$ & 0 \\
\hline & & $\begin{array}{l}\text { Menyebutkan apa yang diketahui tanpa } \\
\text { menyebutkan apa yang ditanyakan atau } \\
\text { sebaliknya }\end{array}$ & 10 \\
\hline & & $\begin{array}{l}\text { Menyebutkan apa yang diketahui dan apa } \\
\text { yang ditanyakan tetapi masih kurang tepat }\end{array}$ & 2 \\
\hline & & $\begin{array}{l}\text { Menyebutkan apa yang diketahui dan apa } \\
\text { yang ditanyakan dengan tepat }\end{array}$ & 3 \\
\hline \multirow[t]{3}{*}{2.} & \multirow{3}{*}{$\begin{array}{l}\text { Merencanakan } \\
\text { Penyelesaian / } \\
\text { mampu membuat } \\
\text { rencana }\end{array}$} & $\begin{array}{l}\text { Tidak merencanakan penyelesaian masalah } \\
\text { sama sekali }\end{array}$ & 0 \\
\hline & & $\begin{array}{l}\text { Merencanakan penyelesaian dengan } \\
\text { membuat gambar berdasarkan masalah } \\
\text { tetapi gambar kurang tepat }\end{array}$ & 1 \\
\hline & & $\begin{array}{l}\text { Merencanakan penyelesaian dengan } \\
\text { membuat gambar berdasarkan masalah } \\
\text { secara tepat }\end{array}$ & 2 \\
\hline \multirow[t]{4}{*}{3.} & \multirow{4}{*}{$\begin{array}{l}\text { Melaksanakan } \\
\text { Rencana / memilih } \\
\text { strategi penyelesaian }\end{array}$} & Tidak ada jawaban sama sekali & 0 \\
\hline & & $\begin{array}{l}\text { Melaksanakan rencana dengan menuliskan } \\
\text { jawaban tetapi jawaban salah atau hanya } \\
\text { sebagian kecil jawaban benar }\end{array}$ & 1 \\
\hline & & $\begin{array}{l}\text { Melaksanakan rencana dengan menuliskan } \\
\text { jawaban setengan atau sebagian besar } \\
\text { jawaban benar }\end{array}$ & 2 \\
\hline & & $\begin{array}{l}\text { Melaksanakan rencana dengan menuliskan } \\
\text { jawaban dengan tepat dan benar }\end{array}$ & 3 \\
\hline \multirow[t]{3}{*}{4.} & \multirow{3}{*}{$\begin{array}{l}\text { Menafsirkan hasil } \\
\text { yang diperoleh / } \\
\text { mampu menjelaskan } \\
\text { dan memeriksa } \\
\text { kembali kebenaran } \\
\text { jawaban }\end{array}$} & Tidak menuliskan kesimpulan & 0 \\
\hline & & $\begin{array}{l}\text { Menafsirkan hasil yang diperoleh dengan } \\
\text { membuat kesimpulan tetapi kurang tepat }\end{array}$ & 1 \\
\hline & & $\begin{array}{l}\text { Menafsirkan hasil yang diperoleh dengan } \\
\text { membuat kesimpulan secara tepat }\end{array}$ & 2 \\
\hline
\end{tabular}

(Siti Mawaddah, 2015:166-167)

Hubungan Model Pembelajaran

Team Accelerated Instruction (TAI) Terhadap Kemampuan Pemecahan Masalah Matematis Siswa

Model Pembelajaran kooperatif tipe TAI mengajak siswa untuk berpikir

secara kreatif dan kritis serta
memberikan variasi dalam belajar. Meskipun model pembelajaran ini menggunakan metode belajar berkelompok, tetapi siswa juga dituntut untuk berdiskusi secara baik tanpa mengulur-ulur waktu belajar. Model 
Pembelajaran kooperatif tipe $T A I$ ini juga melatih siswa untuk mempelajari materi-materi yang diberikan secara cepat dan akurat, sehingga pembelajaran yang dilakukan dikelas tidak hanya terfokus pada guru melainkan siswa juga ikut aktif dalam proses belajar.

Kemampuan pemecahan masalah matematis penting untuk mengetahui dan menyelesaikan masalah matematika. Kemampuan untuk pemecahan masalah menjadikan siswa dapat memecahkan masalah dalam kehidupannya. Dengan demikian siswa diharapkan agar lebih memahami materi pelajaran dan melatih kemampuan pemecahan masalah matematis siswa, sebab pada model pembelajaran koperatif tipe TAI kemampuan pemecahan masalah matematis siswa dituntut untuk dapat berpikir secara lebih luas sehingga siswa dapat terlibat aktif dalam proses belajar.

\section{METODOLOGI PENELITIAN}

Metode yang digunakan dalam penelitian ini adalah metode eksperimen semu kategori one short case study, metode ini merupakan sebuah eksperimen yang dilakukan tanpa adanya kelompok pembanding dan juga tanpa test awal.

Dalam penelitian ini hanya ada satu sampel yaitu kelas yang menjadi eksperimen yang dilaksanakan tanpa ada kelas kontrol (kelas pembanding), yaitu dengan cara menerapkan model pembelajaran kooperatif tipe TAI dalam pembelajaran matematika pada pokok bahasan balok di kelas VIII SMP Negeri 40 Palembang.

Teknik Pengumpulan Data menggunakan Tes dan observasi. Sebelum soal tes digunakan maka terlebih dahulu soal tes diuji cobakan kepada siswa, sehingga peneliti perlu melihat bagaimana soal tes itu dibuat. Karena soal tes yang baik adalah soal tes yang valid dan reliabel, maka peneliti perlu menguji kevalidan dan kereliabelan tes tersebut.

\section{HASIL DAN PEMBAHASAN}

Dari hasil persentase aktivitas belajar siswa secara keseluruhan, didapat aktivitas belajar siswa yang dominan atau yang paling banyak muncul adalah aktivitas siswa membentuk kelompok dan siswa mengerjakan soal tes yang dikerjakan secara individu yaitu sebesar 100 yang artinya semua siswa mengikuti aktivitas ini dengan sangat baik. Dari hasil observasi diatas dapat disimpulkan bahwa kegiatan observasi siswa mengalami peningkatan dari pertemuan pertama dan pertemuan kedua. Dan didapat nilai rata-rata dari sembilan fase yaitu 77,27 yang tergolong ke kategori "baik".

\section{Analisis Data Pemecahan Masalah Matematis}

Hasil kemampuan pemecahan masalah matematis siswa pada pertemuan pertama mendapatkan 60,00 dan pertemuan kedua mengalami peningkatan yaitu sebesar 72,44. Dari pertemuan pertama dan kedua didapatkan rata-rata sebesar 66,22 dan data ini tergolong kategori "cukup". 


\section{SIMPULAN DAN SARAN}

Berdasarkan hasil penelitian dan pembahasan dapat disimpulkan bahwa:

1. Pelaksanaan pembelajaran matematika dengan menggunakan Model Pembelajaran Cooperative Type Team Accelerated Instruction (TAI) dapat diterapkan pada siswa kelas VIII SMP Negeri 40 Palembang, hal ini dapat dilihat dari hasil observasi siswa dengan ratarata 77,27 dengan kategori baik.

2. Kemampuan pemecahan masalah matematis siswa setelah diterapkan Model Pembelajaran Cooperative Type Team Accelerated Instruction (TAI) tergolong kategori baik, hal ini dapat dilihat dari hasil tes akhir dengan nilai rata-rata 84,63.

\section{DAFTAR PUSTAKA}

Arikunto, Suharsimi. 2002. Dasardasar Evaluasi Pendidikan. Edisi Revisi: Jakarta

Arikunto, Suharsimi. 2005.Manajemen Pendidikan. Jakarta: Rineka Cipta.

Arikunto, Suharsimi. 2010. Prosedur Penelitian Suatu Pendekatan Praktik. Jakarta: Rineka Cipta

Sugiyono. 2012. Metode Penelitian Kuantitatif, Kualitatif, dan $R$ \& $D$. Bandung: Alfabeta

Suherman, Erman dkk. 2003. Strategi Pembelajaran Matematika Kontemporer. Bandung: Universitas Pendidikan Indonesia.

Suherman, Erman. 2010. Belajar dan Pembelajaran Matematika. Bandung: Universitas Pendidikan Indonesia

$\begin{array}{ccc}\text { Wena, Made. } & \text { 2009. } & \text { Strategi } \\ \text { Pembelajaran } & & \text { Inovatif } \\ \text { Kontemporer } & \text { Suatu } & \text { Tinjauan }\end{array}$

Konseptual Operasional. Jakarta: PT. Bumi Aksara. 